\title{
PENERAPAN MODEL PEMBELAJARAN DISCOVERY LEARNING UNTUK MENINGKATKAN HASIL BELAJAR PADA MATERI BIOLOGI SISWA SMP
}

\author{
Theresia Inovia Astuti ${ }^{1 *}$, Irdam Idrus ${ }^{1}$, Yennita ${ }^{1}$ \\ ${ }^{1}$ Program Studi Pendidikan Biologi, Fakultas Keguruan dan Ilmu Pendidikan, Universitas Bengkulu \\ Email: theresiainovia.1103@gmail.com
}

\begin{abstract}
Abstrak
Penelitian ini bertujuan untuk mendeskripsikan aktivitas guru dan siswa serta meningkatkan hasil belajar siswa kelas VII SMPN 15 kota Bengkulu. Jenis penelitian ini adalah penelitian tindakan kelas dengan metode deskriptif. Penelitian ini terdiri dari dua siklus, setiap siklus terdiri dari 4 tahapan. Subyek penelitian ini adalah guru dan siswa kelas VII B SMPN 15 Kota Bengkulu. Teknik pengumpulan data dalam penelitian ini yaitu observasi dan tes. Instrumen yang digunakan adalah lembar observasi dan lembar tes. Hasil penelitian menunjukkan bahwa pada siklus I rata-rata skor observasi guru adalah 20,5 yang termasuk kriteria cukup, sedangkan rata-rata skor observasi siswa adalah 20 yang termasuk kriteria cukup. Sedangkan pada siklus II rata-rata skor observasi guru adalah 29,5 yang termasuk kriteria baik, sedangkan rata-rata skor observasi siswa adalah 27,5 yang termasuk kriteria baik. Data hasil belajar pada siklus I dianalisis berdasarkan kriteria ketuntasan belajar klasikal dan di peroleh persentase ketuntasan belajar klasikal pada siklus I yaitu 54,5\% dengan kriteria belum tuntas dan pada siklus 2 nilai rata-rata siswa meningkat menjadi 84,7 \% dengan kriteria tuntas. Kesimpulan dari hasil penelitian menunjukan bahwa penelitian dengan menggunakan model Discovery Learning dapat meningkatkan aktivitas guru, aktivitas siswa dan hasil belajar siswa kelas VII.B SMPN 15 Kota Bengkulu.
\end{abstract}

Kata Kunci : Discovery Learning, Hasil belajar, Pencemaran lingkungan 


\section{PENDAHULUAN}

Standar proses adalah standar nasional pendidikan yang berkaitan dengan pelaksanaan pembelajaran pada satuan pendidikan untuk mencapai kompetensi lulusan. Standar proses meliputi perencanaan proses pem-belajaran, penilaian hasil pembelajaran dan pengawasan proses pembelajaran untuk terlaksananya proses pembelajaran yang efektif dan efisien (Rusman,2014).

IImu Pengetahuan Alam (IPA) berkaitan dengan cara-cara mencari tahu tentang alam secara sistematis, sehingga IPA bukan hanya penguasaan kumpulan pengetahuan yang berupa fakta-fakta, konsep-konsep, atau prinsip-prinsip saja tetapi juga merupakan suatu proses penemuan. Berdasarkan informasi dari guru IPA di kelas VII $\mathrm{B}_{\mathrm{B}} \mathrm{SMPN} 15$ Kota Bengkulu, penguasaan konsep IPA siswa kelas tersebut masih rendah. Hal ini dapat dilihat dari nilai ulangan harian siswa pada materi IPA sebelumnya 48\% siswa dari 33 siswa yang memperoleh nilai diatas kriteria ketuntasan minimal (KKM) 75 yang telah ditetapkan di SMPN 15 Kota Bengkulu.

Faktor yang menyebabkan rendah-nya nilai ulangan siswa ini terjadi karena kurangnya pemahaman konsep, kurang-nya motivasi siswa dalam belajar serta penggunaan strategi pembelajaran yang dilakukan guru kurang tepat, selain itu pembelajaran yang digunakan masih bersifat teacher center oleh sebab itu peneliti mencoba melakukan penelitian dengan mengunakan model Discovery Learning yang mana model pembelajaran ini bersifat student center.

Pembelajaran model Discovery Learning adalah suatu model untuk me-ngembangkan cara belajar siswa aktif de-ngan menemukan sendiri dan menyelidiki sendiri, sehingga akan diperoleh hasil yang akan bertahan lama dalam ingatan serta tidak mudah dilupakan oleh siswa. Dengan teknik ini siswa dibiarkan menemukan sendiri atau mengalami proses mental sendiri, peran guru hanya membimbing dan memberikan instruksi
(Hosnan, 2014). Anam (2016) menyatakan bahwa pembelajaran model Discovery Learning yakni proses pembelajaran yang berfokus pada penemuan masalah (sumber belajar) yang berasal dari pengalaman nyata siswa

\section{METODE}

Jenis penelitian ini adalah penelitian tindakan kelas dengan metode deskriptif. Penelitian ini terdiri dari dua siklus, setiap siklus terdiri dari 4 tahapan yaitu tahap perencanaan, pelaksanaaan, pengamatan dan refleksi. Penelitian ini dilaksanakan pada semester genap tahun ajaran 2016/2017 pada materi pencemaran lingkungan. Subyek penelitian ini adalah guru dan seluruh siswa kelas VII B SMPN 15 Kota Bengkulu dengan jumlah siswa sebanyak 33 siswa yang terdiri dari 14 siswa laki-laki dan 19 siswa perempuan. Peneliti berperan sebagai guru biologi yang mengajar siswa. Peneliti dibantu oleh 2 observer yang bertugas untuk memberikan penilaian atas keterlaksanaan tiap tahapan pembelajaran model Discovery Learning.

Data-data yang akan dikumpulkan ini berupa data aktivitas guru, data aktivitas siswa dan data nilai hasil belajar siswa. Teknik yang digunakan dalam pengumpulan data aktivitas guru dan aktivitas siswa yaitu observasi dengan menggunakan instrumen lembar observasi, sedangkan teknik pengumpulan data untuk hasil belajar siswa yaitu tes tertulis dengan menggunakan instrumen lembar tes.

Hasil observasi aktivitas guru dan siswa dianalisis dengan menentukan kategori rerata berdasarkan skor aspek pembelajaran. Kategori rerata aktivitas guru dan siswa dibagi menjadi 3, yaitu baik, cukup, dan kurang. Penentuan kate-gori skor menggunakan rumus:

$$
C=\frac{X n-X 1}{k}
$$

Sudijono (2012)

Keterangan :

$\mathrm{Xn}=$ Skor tertinggi (jumlah butir pengamtan $\mathrm{x}$ skor maksimum setiap butir) 


$$
\begin{aligned}
\mathrm{X} 1= & \text { Skor terendah (jumlah butir } \\
\text { pengamatan } \mathrm{x} \text { skor minimum setiap } & \text { butir) } \\
\mathrm{K}= & \text { Jumlah Kategori }
\end{aligned}
$$

Adapun kriteria dari masing-masing kategori dapat dilihat pada Tabel 1 .

Tabel 1. Kategori Rerata Skor Aktivitas Guru Dan Siswa

\begin{tabular}{cc}
\hline Rerata Skor & Kategori \\
\hline$\geq 27$ & Baik \\
$19-26$ & Cukup \\
$\leq 18$ & Kurang \\
\hline
\end{tabular}

Data hasil belajar siswa dianalisis dengan menghitung rerata skor yang diperoleh dan persentase ketuntasan belajar seluruh siswa. Kategori rarata skor mengacu pada kriteria ketuntasan minimum (KKM) SMPN 15 Kota Bengkulu yaitu $\geq 75$ (berkategori tuntas) dan $\leq 75$ (berkategori belum tuntas). Persentase ketuntasan belajar siswa secara klasikal dihitung dengan rumus:

$$
\mathrm{KB}=\frac{N S}{N} x \quad 100 \%
$$

Keterangan:

KB : Persentase ketuntasan belajar

NS: Jumlah siswa yang mendapat nilai $\geq 75$

$\mathrm{N}$ : Jumlah siswa

\section{HASIL DAN PEMBAHASAN}

Penelitian mengenai penerapan model discovery leraning pada materi Pen-cemaran lingkungan secara keseluruhan berdampak positif terhadap peningkatan aktivitas guru, aktivitas siswa serta hasil belajar siswa kelas VIIB SMPN 15 Kota Bengkulu. Hal ini diketahui berdasarkan data-data yang diperoleh dari pelaksanaan siklus I dan siklus II pembelajaran. Setelah dilakukan tindakan selama dua siklus akhirnya target penelitian

\begin{tabular}{|c|c|c|c|c|c|c|c|c|c|}
\hline \multirow{3}{*}{ No } & \multirow{3}{*}{$\begin{array}{l}\text { Tahapan } \\
\text { Model } \\
\text { Discovery } \\
\text { Learning }\end{array}$} & \multicolumn{4}{|c|}{ Siklus I } & \multicolumn{4}{|c|}{ Siklus II } \\
\hline & & \multicolumn{2}{|c|}{ Aktivitas Guru } & \multicolumn{2}{|c|}{ Aktivitas siswa } & \multicolumn{2}{|c|}{ Aktivitas Guru } & \multicolumn{2}{|c|}{ Aktivitas Siswa } \\
\hline & & $\begin{array}{l}\text { Rerata } \\
\text { skor }\end{array}$ & Kategori & $\begin{array}{l}\text { Rerata } \\
\text { skor }\end{array}$ & Kategori & $\begin{array}{l}\text { Rerata } \\
\text { Skor }\end{array}$ & Kategori & $\begin{array}{l}\text { Rerata } \\
\text { Skor }\end{array}$ & Kategori \\
\hline 1 & $\begin{array}{l}\text { Pemberian } \\
\text { rangsangan }\end{array}$ & 2,5 & Baik & 2,25 & Cukup & 2,5 & Baik & 2,75 & Baik \\
\hline 2 & $\begin{array}{l}\text { Identifikasi } \\
\text { masalah }\end{array}$ & 2 & Cukup & 2 & Cukup & 2,5 & Baik & 3 & Baik \\
\hline 3 & $\begin{array}{l}\text { Pengumpulan } \\
\text { data }\end{array}$ & 1,5 & Kurang & 2 & Cukup & 3 & Baik & 2,25 & Cukup \\
\hline 4 & $\begin{array}{l}\text { Pengolahan } \\
\text { data }\end{array}$ & 1,75 & Cukup & 1,25 & Kurang & 2,75 & Baik & 2,5 & Baik \\
\hline 5 & Pembuktian & 1,75 & Cukup & 2 & Cukup & 2,25 & Cukup & 2,5 & Baik \\
\hline 6 & $\begin{array}{l}\text { Menarik } \\
\text { kesimpulan }\end{array}$ & 1,75 & Cukup & 1,5 & Kurang & 2,75 & Baik & 2,25 & Cukup \\
\hline
\end{tabular}
dapat tercapai. Data mengenai aktivitas guru dan siswa dengan menerapakan model Discovery Learning dapat dilihat pada Tabel 2.

Tabel 2. Data Aktivitas Guru Dan Aktivitas Siswa Pada Pembelajaran Model Discovery Learning

Dalam proses pembelajaran, aktivitas guru dan siswa merupakan faktor yang sangat penting dalam upaya peningkatan hasil belajar siswa. Dalam kegiatan belajar mengajar, pelaksanaan tindakan menunjukkan adanya perbedaan antara aktivitas guru dan aktivitas siswa. Guru mendorong siswa untuk memiliki pengalaman serta melakukan percobaan, dan siswa belajar melalui keterlibatan keaktifan mereka sendiri. Hal ini terlihat 
dari hasil analisis observasi aktivitas guru dan aktivitas siswa di setiap siklusnya.

Dari penjabaran aktivitas guru dan siswa dalam tahap Discovery Learning, diketahui bahwa aktivitas guru sangat menentukan keaktifan siswa. Artinya jika aktivitas guru dalam mel-kukan pengajaran di kelas sudah baik, maka aktivitas siswa pun juga akan ikut baik. Hal ini didukung oleh pendapat Dimayanti dan Mujiono (2006) yang menyatakan belajar yang dihayati oleh seorang pembelajar (siswa) ada hubungannya dengan usaha pembelajaran yang dilakukan pembelajar (guru). Adapun grafik perkembangan aktivitas guru dan aktivitas siswa dapat dilihat pada Gambar 1.

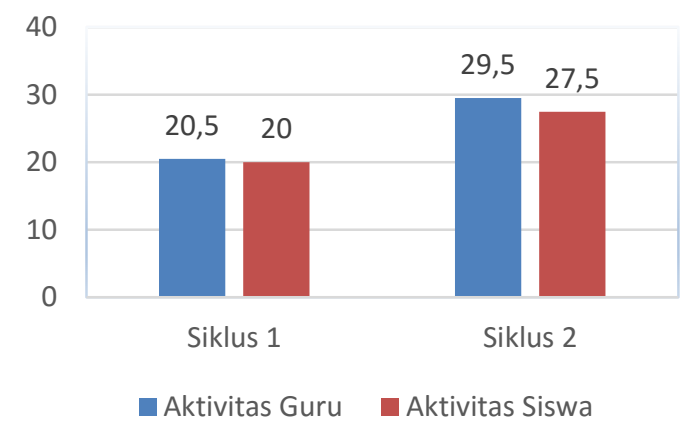
Gambar 1. Peningkatan Aktivitas Guru Dan
Siswa Pada Tiap Siklus

Adapun untuk nilai rata-tata dan persentase ketuntasan hasil belajar siswa berdasarkan model Discovery Learning dapat dilihat pada Tabel 2.

Tabel 2. Nilai Rata-Rata Kelas Dan Persentase Ketuntasan

\begin{tabular}{cccc}
\hline Siklus & $\begin{array}{c}\text { Rata- } \\
\text { rata Nilai }\end{array}$ & $\begin{array}{c}\text { Jumlah } \\
\text { siswa } \\
\text { yang } \\
\text { tuntas }\end{array}$ & Persentase \\
\hline I & 74,5 & 18 & $54,4 \%$ \\
II & 82,2 & 28 & $84,8 \%$ \\
\hline
\end{tabular}

Dari Tabel 2, nilai rerata kelas dan persentase ketuntasan belajar mengalami peningkatan disertai bertambahnya jumlah siswa yang mendapatkan nilai post-test $\geq 75$. Hal ini menunjukkan secara keseluruhan bahwa soal post-test yang diberikann mampu dijawab benar oleh siswa. Peningkatan hasil belajar siswa ini selaras dengan penelitian yang dilakukan Melani (2012) yang menyatakan bahwa model Discovery Learning memiliki pengaruh dalam meningkatkan hasil belajar biologi siswa. Hal ini terjadi karena pembelajaran model Discovery Learning mengembangkan cara belajar aktif dimana siswa menemukan sendiri, menyelidiki sendiri maka hasil yang akan diperoleh akan setia dan tahan lama dalam ingatan, serta tidak mudah dilupakan oleh siswa. Penelitian lain yang dilakukan oleh Sartika (2016) menyatakan bahwa penerapan model Discovery Learning dapat meningkatkan hasil belajar siswa.

Oleh karena itu, apabila setiap tahapan pada model Discovery Learning dilaksanakan dengan baik, maka siswa juga memperoleh pengetahuan yang sifatnya membangun sendiri pengetahuan tersebut melalui model Discovery Learning. Hal ini sesuai dengan pernyataan Hosnan (2014) bahwa model Discovery Learning adalah suatu model untuk mengembangkan cara belajar siswa aktif dengan menemukan sendiri dan menyelidiki sendiri.

\section{PENUTUP}

Simpulan

Dari hasil penelitian mengenai penerapan model Discovery Learning pada mata pelajaran IPA di kelas VII.B SMPN 15 Kota Bengkulu maka dapat ditarik kesimpulan sebagai berikut:

1. Pembelajaran menggunakan model Discovery Learning pada mata pelajaran IPA dikelas VII.B SMPN 15 Kota Bengkulu dapat meningkatkan aktivitas guru dan siswa selama proses pembelajaran pada pokok bahasan Pencemaran Lingkungan.

2. Perbaikan pembelajaran menggunakan Discovery Learning pada mata pelajaran IPA di kelas VII.B SMPN 15 
Kota Bengkulu dapat meningkatkan hasil belajar siswa selama proses pembelajaran pada pokok bahasan Pencemaran Lingkungan.

\section{Saran}

Berdasarkan hasil penelitian yang telah dilaksanakan, berikut beberapa saran yang dianjurkan yaitu:

1. Kepada guru mata pelajaran IPA biologi SMPN 15 Kota Bengkulu, diharapkan agar dapat menggunakan model pembelajaran Discovery Learning dengan tahapan pembelajaran yang tepat untuk diterapkan pada pembelajaran IPA sebagai upaya meningkatkan hasil belajar siswa.

2. Dalam menerapkan model pembelajaran Discovery Learning diharapkan guru dapat menguasai setiap tahaptahap yang terdapat pada model ini dengan baik dan dapat mendesain serta memadukan pembelajaran model Discovery Learning dengan metode belajar dan bermain agar pembelajaran menjadi menyenangkan serta peningkatan hasil belajar menjadi lebih tinggi.

\section{DAFTAR PUSTAKA}

Anam, Khoirul. 2016. Pembelajaran Berbasis Inkuiri Metode Dan Aplikasi. Yogyakarta :Pustaka Pelajar.

Dimyati dan Mudjiono. 2002. Belajar dan Pembelajaran. Jakarta: PT Rineka Cipta.

Hosnan, 2014. Pendekatan Saintifik Dan Kontekstual Dalam Pembelajaran Abad 21.Bogor : Penerbit Ghalia Indonesia.

Melani,R.2012. Pengaruh Metode Guide Discovery Learning Terhadap Sikap Ilmmiah dan Hasil Belajar Kognitif Biologi SMA N 7 Surakarta Tahun pelajaran 2011/2012.

(http://eprints.uns.ac.id/13651/1/1 409-3135-1-SM.pdf.

Rusman, 2014. Model-model Pembelajaran Mengembangkan Profesional Guru. Jakarta: Rajawali Press.

Sartika, D. 2015. Upaya Meningkatkan Hasil Belajar Biologi dengan Penerapan Model Pembelajaran Penemuan (Discovery Learning) Materi Sistem Ekskresi pada Manusia Kelas VIII.6 SMPN 1 Kota Bengkulu. Skripsi tidak diterbitkan. Bengkulu: Universitas Bengkul 